Varga Norbert

\title{
A POLGÁRMESTER HATÁSKÖRE AZ 1870: XLII. TC. ALAPJÁN ${ }^{1}$
}

\author{
Mayoral Jurisdiction Based on Act XLII of 1870
}

Dr. Varga Norbert, egyetemi docens, Szegedi Tudományegyetem Államés Jogtudományi Kar Magyar Jogtörténeti Tanszék, vargan@juris.u-szeged.hu

A polgári közigazgatás kiépitésének egyik jelentős lépése volt a törvényhatósági jogú városok elsö számú választott tisztviselöjének, a polgármester hatáskörének meghatározása, a müködéséhez kapcsolódó hivatalok feladatkörének rendezése és a helyettesitésére vonatkozó szabályok rögzitése. A rendi idöszakból már ismert városi tisztviselö szerepét az is kiemelte, hogy a törvényhatósági jogú városok élére is fóispánokat állitott az 1870: XLII. törvénycikk. A föispán a kormány érdekeit képviselte és közvetítette a városokban. A polgármester mint a törvényhatósági jogú városok választott tisztviselője azonban a helyi érdekek érvényesitését tartotta szem elött. Magának az elnevezésnek általánossá tétele is a köztörvényhatósági törvénynek köszönhetö a magyar közigazgatásban, hiszen a rendi korban inkább a fóbíró elnevezést használták, és csak kivételesen jelent meg a polgármesteri tisztség elnevezése a városok életében. A rendiség vége felé jelent meg egyre több városban a polgármesteri tisztség.

KulCsSzavaK:

közigazgatás, polgármester, helyi önkormányzat, dualizmus, magyar közigazgatás-történet

The rights and obligations of a mayor, the scope of duties of the primary office-holder of municipal towns were determined by Act XLII of 1870. The duties and proceedings of the mayor were regulated in detail by the towns, and by this method, they made clear that the mayor is the primary office-bearer of the municipality, and thus, bore an extremely significant set of political and administrative legal powers. This study is going to provide a description of the scope of duties of a mayor, especially the rights of this office in connection to the office-holders of towns, its fulfilled

A mű a KÖFOP-2.1.2-VEKOP-15-2016-00001 azonosítószámú, „A jó kormányzást megalapozó közszolgálat-fejlesztés" elnevezésű kiemelt projekt keretében működtetett Államtudományi Kutatómühely keretében, a Nemzeti Közszolgálati Egyetem felkérésére készült. 
role within the committee of the municipality and the fulfilment of administrative tasks. In the everyday life of a town, the role of mayor did not only play a significant political role, and not only did he supervise the actual administrative proceedings, but also safeguarded their effectiveness. Among the office-bearers, it was the duty of a mayor to assure the protection of a city's interest against government objectives, the fulfilment of which was tasked to the comes (föispann). Therefore, the election and the actions of a mayor affected the administration of municipal towns immeasurably, to which archival examples will be provided within the framework of this essay.

\section{Keywords:}

mayor, public administration, local government, dualism, administration history in Hungary 


\section{BEVEZETŐ}

A kiegyezést követően az 1870: XLII. tc. szabályozta a törvényhatósági jogú városok szervezetét. A városok első számú tisztségviselője volt a polgármester, akinek hatáskörének megállapítása volt az egy legfontosabb közigazgatási feladat. Ez jelentette a közigazgatás hatékony müködésének helyi szinten történő garanciáját. A polgármester mint a törvényhatósági jogú városok első számú választott tisztviselője a város érdekeit képviselte a törvényhatósági bizottsági ülésen. A polgármesternek kiemelt szerep jutott a helyi közigazgatási élet vezetésében, amelyre tekintettel különösen fontosnak tartottam feladatkörének vizsgálatát és bemutatását.

A köztörvényhatósági törvény hatálybalépését követően „kivétel nélkül minden város élén polgármesternek nevezett tisztviselő áll, a ki valóságos feje a városi közigazgatásnak, képviselője, megszemélyesítője a város közösségének. A polgármesteri állás hatásköre jellege tekintetében lényeges különbséget okoz a város törvényhatósági, vagy rend. tanácsi jellege.”2 Jelen tanulmány keretében a törvényhatósági jogú városok élén álló polgármester hatáskörével és működésével kapcsolatos szabályokat, azok gyakorlati érvényesülését és a feladatának ellátásához szükséges hivatalok működését kívánom röviden bemutatni. A községi törvény (1871: XVIII. tc.) által szabályozott rendezett tanácsú városok élén álló polgármester vizsgálata tehát nem képezi e tanulmány tárgyát. Elöször általánosságban ismertetem a polgármester hatáskörét, amelyet követően Szeged és Debrecen példája alapján kívánom elemezni a tényleges gyakorlatot.

A törvényhatósági jogú város élén álló polgármester jogait és kötelezettségeit az 1870: XLII. tc. rögzítette. ${ }^{3}$ A törvényhatóság hatásköre kapcsán rögzítették, hogy

Nagy Ferencz: A magyar városi jog. Franklin, Budapest, 1912. 225.

A köztörvényhatóságok rendezéséról szóló 1870: XLII. tc. 4., 30., 38., 41., 42., 47., 51., 53., 63., 78. és a 87. \$\$-aira tekintettel megjegyezhető, hogy a polgármester hatásköre jóval kevesebb ügyre terjedt ki, mint a vármegyében az alispánnak. Közel sem volt annyira egyszemélyi vezetője a városnak, mint az alispán a vármegyének. Sarlós Béla: Közigazgatás és hatalompolitika a dualizmus rendszerében. Budapest, Akadémiai Kiadó, 1976. 91-92.; Csizmadia Andor - Kovács Kálmán - Asztalos László: Magyar állam- és jogtörténet. Budapest, Nemzeti Tankönyvkiadó, 1998. 354.; Meznerics Iván - Torday Lajos: A magyar közigazgatás szervei 1867-1937. Budapest, Magyar Közigazgatástudományi Intézet, 1937. 59.; Pétervári Máté: Ereky István élete és munkássága, tekintettel a 19. század második felében történt közigazgatási reformokra. Jogtörténeti Szemle, (2014), 3. 29-38.; Papp László: Az önkormányzatiság vázlatos áttekintése, különös tekintettel a hosszú 19. század alkotmányos megoldásaira. De Jurisprudentia et Iure Publico: Jog-és Politikatudományi Folyóirat, 6. (2012), 1-2. 1-11.; Papp László: The concept of autonomous local governments and their different forms of appearances in the tradition of our national public law. Journal on European History on Law, 3. (2012), 1. 62-65.; Antal Tamás: Város és népképviselet. Az 1848:XXIII. tc. és intézményei Debrecenben (1848-1872). Szeged, Pólay Elemér Alapítvány, 2011. 180-183. A tisztségről: Gárdonyi Albert: A polgármesteri tisztség eredete és fejlődése hazánkban. Városi Szemle, 25. (1939). 359-370. A közigazgatásban alkalmazott hivatalnokokról: Pétervári Máté: The History of Hungarian Civil Service from the Austrian-Hungarian Compromise of 1867 to the First World War. Journal on European History on Law, 8. (2017), 1. 116-120.; Kajtár István: Magyar városi önkormányzatok (1848-1918). Budapest, Akadémiai Kiadó, 1992. 155-156.; Pétervári Máté: A szolgabírói hivatal az 1870. évi XLII. törvénycikk alapján. Pro Publico Bono - Magyar Közigazgatás, (2018), 3. 56-78.; Pétervári Máté: Az igazságszolgáltatás és a közigazgatás elválasztása járási szinten. Acta Universitatis Szegediensis: Forum: Acta Juridica et Politica, 8. (2018), 1. 241-253.; Pétervári Máté: A járások polgári kialakítását befolyásoló tényezők az 1870: XLII. tc. vég- 
a magánszemélyek a törvényhatóságokáltal önkormányzati hatáskörükben hozott sérelmes határozatai ellen a kézbesítéstől számított 15 napon belül az illetékes miniszterhez fordulhattak. Erre vonatkozó folyamodványt a polgármesterhez kellett eljuttatni, aki azt nyolc napon belül véleményes jelentésével együtt felterjesztette a miniszterhez.

\section{A POLGÁRMESTER HATÁSKÖRE}

Külön ki kell térni a polgármesternek a kormányrendeletek végrehajtása kapcsán rögzített jogosítványainak rövid bemutatására is. A törvényhatóságok hatáskörébe tartozott, hogy felirattal élhettek a kormányrendeletek végrehajtása előtt, ha azt törvénybe ütközőnek vélték, vagy a helyi viszonyok közepette célszerütlennek tartották. ${ }^{4}$ Az eseti jellegü kormányrendeleteknél gyakrabban elöfordult, hogy törvénytelen rendelkezéseket tartalmaztak. Ezt a jogot a törvényhatósági bizottság közgyűlése gyakorolhatta, de csak egyszer. A miniszter a felhozott indokok ellenére azonban követelhette a rendelet végrehajtását.

Az első lépés az volt, hogy a kormány egy rendeletet megküldött a törvényhatóságoknak végrehajtásra. Ha ezt jogellenesnek vagy a helyi viszonyok között nem teljesíthetőnek vélte a törvényhatóság első számú tisztviselője, akkor erről 24 órán belül írásbeli jelentést készített a föispánnak. A főispán erről indokolt felterjesztést tett a kormánynak. A polgármester csak akkor küldhette meg észrevételét közvetlenül a kormánynak, ha a föispán távol volt. Ez nem jelentette a felirati jog gyakorlását, hanem csak a kormány azonnali tájékoztatását. Ez a felterjesztés nem sértette a kormány érdekeit, épp ellenkezőleg, felhívta a kormány figyelmét az esetleges helytelen szabályozásra. Az „inter” úton történt kiigazítás célszerủbbé tehette a közigazgatás rendszerét. ${ }^{5} \mathrm{Ha}$ a miniszter nem támogatta a felterjesztést, akkor a polgármester vagy végrehajtotta a miniszter rendeletét, vagy pedig a törvényhatósági bizottság élt felirati jogával.

A főispán vezette azt a rendkívüli közgyülést, amelyen megvitatták az érintett rendeletet és meggátolhatta, hogy a városok „törvényhatósági obstrukcióval” megakadályozzák

rehajtása során. In P. Szabó Béla et. alii (szerk.:) Profectus in Litteris IX. Előadások a 14. debreceni állam- és jogtudományi doktorandusz-konferencián. Debrecen, Lícium-Art, 2017. 234.

4 Irinyi Károly: A politikai közgondolkodás és mentalitás változatai Debrecenben 1867-1918. Debrecen, DE Történelmi Intézet, 2002. 37.; Csorba László: A dualizmus rendszerének kiépülése és a konszolidált időszak (18671890). In Gergely András (szerk.): 19. századi magyar történelem 1790-1918. Budapest, Korona, 1998. 380.; Balogh Arthur: A magyar államjog alaptanai. Budapest, Franklin, 1901. 307.; Hencz Aurél: Területrendezési törekvések Magyarországon. Az államigazgatási jogi szabályozás aspektusából. Budapest, Közgazdasági és Jogi Kiadó, 1973. 103.; Gergely András: Területi autonómiák - lokális önkormányzatok a XIX. századi Magyarországon. In Gergely Jenő - Strausz Péter - Zachar Péter Krisztián (szerk.): Autonómiák Magyarországon 18481998. Budapest, ELTE Bölcsészettudományi Kar, 2004. 52.

5 Ennek a közigazgatási aktusnak semmi köze nem volt az 1848 előtt ismert vis inertiae-hez. Sarlós (1976) i. m. 49. Ezzel szemben Mezey Barna a felirati jogot a vis inertiae „halvány lenyomataként” említi. A felirati jog révén azonban már kevésbé lehetett az országos politikát befolyásolni. Mezey Barna: Államosítás és autonómia. Centralizáció és önkormányzatiság a XIX. század második felében. In Gergely Jenő (szerk.): Autonómiák Magyarországon 1848-1998. Budapest, ELTE Bölcsészettudományi Kar, 2004. 22. 
a végrehajtást. Ezért aztán egyet lehet érteni Sarlós Béla megállapításával, amely szerint: „A miniszternek tehát teljes és korlátlan diszkrecionális joga van a törvényhatóság által hozott valamennyi határozattal kapcsolatban. Ezzel a diszkrecionális joggal a miniszter mindenkor megakadályozhatja, hogy a törvényhatósági önkormányzat vagy a törvényhatóság által gyakorolt közigazgatás szembe kerüljön a kormánypolitikával, feltétlenül biztosítani tudja az önkormányzat, a középfokú közigazgatás és kormánypolitika teljes összhangját."6

Az átszervezés következtében a kormány befolyása csak erösödött a törvényhatóságok autonómiájának gyengülése mellett. „A törvényhatósági autonómia jogkörének szűkítési tendenciája már az 1870. évi törvényhatósági törvényben jelentkezett. A kormány centralizációs törekvéseit nemcsak a dualizmus politikája, közjogi konstrukciója tette szükségessé," hanem a fejlődő gazdasági rendszer is. ${ }^{7}$ A törvényhatóságok a felirati jog révén gyakorolhatták alkotmányvédő szerepüket.

A polgármester a törvényhatósági bizottság tagjainak megválasztása kapcsán az igazolt tagok névsorát tájékoztatás végett közzétette, és a választás napját kellő időben kihirdette. Erre példát is találhatunk a Debreczen című napilap hasábjain. „Az általános tisztújítás határidejéül f. é. július 31-ének délelőtti 9 órája kitűzetvén, főispán úr megkeresése folytán közhírré tétetik, hogy mindazok, kik a köztörvényhatóságok rendezéséről szóló törvényben kijelölt hivatalok valamelyikére választás, illetőleg kinevezés útján, alkalmaztatni kívánnak ebbeli nyilatkozataikat írásban vagy szóval f. évi július 23-tól júl. 29-ike délelőtti 12 óráig főispán úr ő méltóságához a városházánál levő hivatali helyiségébe naponként délelőtti 10 órától 12 óráig annál bizonyosabban adják be, mert a kitűzött határidő után a kijelölő választmány munkálkodását megkezdvén, későbbi jelentkezések figyelembe nem vétethetnek."

Amennyiben vitás kérdés merült fel az igazolási választmány határozataival szemben, akkor a törvényhatósági bizottság által három évre választott öttagú állandó bíráló választmányhoz lehetett fellebbezést benyújtani, amelynek elnöke a főispán volt, akit akadályoztatása esetén a törvényhatósági jogú városokban a polgármester helyettesített.

A közgyülés, vagyis a törvényhatósági bizottság elnöke a föispán volt, akit a polgármester helyettesíthetett szükség esetén, aki rendkívüli közgyülést is összehívhatott. A törvényhatósági bizottsági ülésen a polgármester jelen lehetett, és szavazati joga is volt, még akkor is, ha a bizottságnak egyébként nem volt tagja.

A főispán a végrehajtó hatalom képviselőjeként vizsgálatot rendelhetett el a hanyag és vétkes tisztviselővel szemben, és a vizsgálat időtartamára felfüggeszthette hivatalából. E jogkörét a polgármester csak a belügyminiszter jóváhagyása mellett gyakorolhatta.

A törvény 63. \$-a konkrétan felsorolta a város első számú hivatalnokának hatáskörébe tartozó fontosabb feladatokat. Elnöke volt a városi tanácsnak; intézkedett azon ügyekben, amelyek a törvény vagy szabályrendelet értelmében hatáskörébe tartoztak; átvette

Sarlós (1976) i. m. 46-53.

Uo. 25.

Debreczen, 1872. július 22. Kovács Lajos polgármester által közzétett felhívás. 
a városhoz intézett kormányrendeleteket, leveleket, jelentéseket és folyamodványokat; végrehajtotta a kormányrendeleteket; aláírta a város nevében kiállított okmányokat, leveleket és felterjesztéseket; őrizte a város pecsétjét; a törvényhatósági bizottság számára jelentéseket készített a város állapotáról és felvette a városi szolgákat.

Ezt követően vizsgáljuk meg, hogy Szeged és Debrecen hogyan szabályozta a polgármester hatáskörét.

A törvény idézett szakaszaiban meghatározott jogok és kötelezettségek alapján a gyakorlatban Szegeden a polgármester beosztotta és áthelyezte a tanácsnokokat, illetve a segédszemélyzetet az egyes osztályokba. ${ }^{9}$

Ellátta a tisztikarnak, a segéd- és a kezelöszemélyzetnek, valamint a szolgáknak a közgyülés számára fenn nem tartott személyi és illetményi ügyeit, és nyolc napot meg nem haladó szabadság engedélyezése iránti kéréseit teljesítette. A közgyűléshez a tanáccsal egyetértésben indokolt javaslatot terjesztett be az új hivatalok fölállítása vagy a régiek megszüntetése iránt.

Szegeden és Debrecenben egyaránt az évente előforduló rendkívüli munkák teljesítésére és időtartamára fölvette a közgyűlés által engedélyezett napidíjas írnokokat, továbbá a föjegyző, illetve adóügyi előadó meghallgatása mellett kinevezte a kézbesítőket, az adóvégrehajtókat, az adóintőket, az előbbieket a rendkívüli munka megszűntével, az utóbbiakat kötelességeik hütlen vagy pontatlan teljesitése esetén el is bocsájthatta.

Rendelkezett a törvényhatóság tisztviselőivel, a segéd- és a kezelöszemélyzettel, és ha hivatalos kötelességüknek teljesítése során szabálytalan módon jártak el, a teendők elvégzésével más tisztviselőt bízott meg, a hanyag tisztviselő fizetésének rovására utalványozott napdíj kiszabása mellett.

A két város polgármestere megállapította a segéd- és a kezelőhivatalokban a munkabeosztást az illetékes hivatal vezetőjével egyetértve. Vizsgálatot rendelhetett el a segédés a kezelőszemélyzet hanyag és vétkes tagjai ellen és helyettesíthette őket. A felfüggesztett tisztviselők ellen hozott döntéseket a közgyűlés elé terjesztette. Elintézte a tisztikar, a segéd- és a kezelőszemélyzet, valamint a szolgáknak a közgyűlés elé nem tartozó személyi és illetményi ügyeit, a 14 napot meg nem haladó szabadságolási kérvényeit. Ez azonban Szegeden részben a közgyűlés hatáskörébe tartozott.

Jelentést tett a közgyülésnek az 1870: XLII. tc. 58. \$-a alapján az elnökileg elintézett ügyekről. Beszámolt minden rendes közgyülés kezdetén a városban időközben elöfordult fontosabb eseményről, a köz- és beligazgatásban felmerült lényegesebb mozzanatokról, a „közbátorság”, a közegészség állapotáról és a pénztári számadásról.

Erre vonatkozó gyakorlatot a következő levéltári forrás ismertetésével kívánom alátámasztani. A szegedi törvényhatósági bizottsági rendes közgyűlését Dáni Ferenc, Szeged,

A polgármesterről általában: Sarlós (1976) i. m. 78.; Csizmadia Andor: A magyar közigazgatás fejlődése a XVIII. századtól a tanácsrendszer létrejöttéig. Budapest, Akadémiai Kiadó, 1976. 124. Eöttevényi Nagy is a polgármestert említi a törvényhatósági jogú városok elsőszámú tisztviselöjeként. Eöttevényi Nagy Olivér: A magyar közjog tankönyve. Kassa, Vitéz, 1911. 257. 
Kecskemét és Arad városok kormánypárti főispánja, ${ }^{10}$ nyitotta meg, ahol a polgármester ismertette a város helyzetét bemutató havi jelentését. A közegészségügyi állapottal kapcsolatban kijelentette, hogy 1872. év elejétől kezdve jelentkezett himlő még mindig szórványosan felütötte fejét a városban, de nem aggasztó mértékben. A „közbátorság”, vagyis a városi rendészet körébe tartozó ügyek kapcsán a polgármester kijelentette, hogy csak jelentéktelen kihágások és testi sértések történtek a város területén. Megemlítette azt is, hogyan haladt a katonák besorozása. Problémaként emelte ki azonban a „vadvizek” elvezetését, a csatornázást és az árkolást, ami alapvetően a városi külterületeket és a vasútvonal használatát veszélyeztette. A Tisza rendkívüli áradása miatt is megtették a szükséges lépéseket a városban. A jogi ügyek kapcsán hangsúlyozta, hogy a városi perek száma növekedett, amelyet a tiszti ügyész által készített negyedéves táblázatos kimutatással támasztott alá. A polgármester a város pénzügyi helyzetének aktuális ismertetésével zárta havi jelentését. ${ }^{11}$

A polgármester éves jelentést is készített, amelyben strukturáltan, az egyes közigazgatási feladatokra fókuszálva ismertette a változásokat. Így tett a szegedi polgármester 1875ben is, amikor az 1874. évi hatósági müködésről szóló jelentését beterjesztette a törvényhatósági bizottságnak. A költségvetési ügyek körében mutatta be a város bevételeinek és kiadásainak alakulását az előző évre vonatkozóan. A szigorú költségvetési szabályok elöírása mellett a kiadások növekedését is hangsúlyozta. Külön is említette a kórházi építkezést, a Tisza parti közlekedés kialakítását, a vár romjainak eltakarítását és többek között az újszegedi hídfő kiépítését. A rendőri viszonyok alatt arról számolt be a polgármester, hogy a súlyosabb büncselekmények száma alacsony maradt (két gyilkosság, egy emberölés történt). A rendőrség munkáját statisztikai adatokkal támasztotta alá. Kitért a tüzoltóság munkájának bemutatására is. Az árvízvédelemmel kapcsolatban jelentkezett problémákat is ismertette. Az ipari és a kereskedelmi engedélyek kiállításának nagyságát számadatokkal támasztotta alá. Hangsúlyozta, hogy egy új gyógyszertár felállítása is szükségesnek mutatkozik. A pénzügyek körében kiemelte, hogy a városnak „nyomasztó pénzügyi viszonyai” vannak, amelyeket csak súlyosbított a hitel összegének emelkedése. Ez összességében növelte a város úgynevezett „szenvedő” tőkéjének a nagyságát.

A felügyelete alatt álló pénztárakat a szervezeti szabályrendelet értelmében évente többször is ellenőrizte és megvizsgálta. Ennek ellenére a polgármester beszámolt egy sikkasztási ügyröl, amelyet Árvai József, volt pénztári segédtiszt követett el 2300 forint összeg értékben. Ezért vele szemben megindították a fegyelmi eljárás kapcsán a vizsgálatot. A polgármester éves jelentésében kiemelte, hogy a város tudományos és humanitárius célra adományokat kapott, mint például a Dugonics szobor elkészítésére. Ismertette a város pénzforgalmi egyenlegét, a szegényügyi és a közmunkaalap pénzügyi hátterét. Az egészségügy kapcsán hangsúlyozta, hogy a minisztériumi ellenőrzés során a kórházak állapotát kielégítőnek találták. A szegények segélyezésére külön bizottságot állítottak fel, és a koldulást

A Hon, 8. (1870), 154. 1. Dáni Ferencz utóbb Szeged és Hódmezővásárhely főispánja lett.

1 Magyar Nemzeti Levéltár Csongrád-Csanád Megyei Levéltára, (MNL CSCSML) Szeged város törvényhatósági bizottságának jegyzőkönyvei IV. B. 1402. 1867-1944. 1872:172. 
betiltották. A törvényhatóság területére vonatkozó halotti, születési és házasságkötési statisztikát is ismertette. Előadásának végén pedig kitért a várossal kapcsolatos jogi és oktatási ügyek bemutatására, különösen az ingatlanviszonyok tisztázására, a legelőelkülönítésre, a városi szenvedő perekre (például a kártérítési perekre), a határrendezésre és Újszeged bekebelezésének tervére. Végezetül pedig az iskolák helyzetét és az oktatással kapcsolatos célokat tárta a képviselők elé. ${ }^{12}$

A polgármester végrehajtotta a közgyűlés által hozzá utalt és a magánszemélyeket érintő határozatait. Elrendelte a szabályrendeleteknek dobszó melletti és kifüggesztés útján történő kihirdetését. A pénztárak megvizsgálását elvégezte, amikor azt szükségesnek vélte, de legalább negyedévente egy alkalommal, és az erről szóló jelentést a közgyűlés elé terjesztette.

Debrecenben a polgármester hatáskörét, amely némi eltérést mutat a szegeditől, a következőképpen szabályozták. A törvény értelmében a polgármester elnöke volt a tanácsnak és a főispán akadályoztatása esetében a közgyűlésnek is. Szavazattal rendelkező rendes tagja volt a testületi szerveknek. Rendkívüli közgyülést hívhatott össze. Intézkedett azon ügyekben, amelyek a törvény vagy a szabályrendeletek értelmében a polgármester hatásköréhez tartoztak. Átvette a városhoz intézett kormányrendeleteket, leveleket, jelentéseket és folyamodványokat. Aláírta a város nevében kiállított okmányokat, leveleket és felterjesztéseket. Örizte a város pecsétjét. A közgyűlésnek és a főispánnak jelentést tett intézkedéseiről és évenként legalább egyszer a város állapotáról. A főispán akadályoztatása esetében ellátta a bíráló választmány elnökségét. Gondoskodott a rendes és a rendkívüli közgyűléseken előadandó tárgyak sorozatának időbeni közzétételéről. Megvizsgáltatta a pénztárakat és a tisztviselők eljárását. Ellenőrizte az ügykezelést. A polgármester hatáskörébe tartozott a házasságok esetében szükséges kihirdetések alóli felmentés megadása. Debrecenben a házi pénztári be- és kiutalványozásokat is teljesítette, az utóbbiakat azonban a költségvetés körén belül, lehetőleg a magánlevéltári bizottmánynak a megkeresésére. Gondoskodott arról, hogy a tisztviselők a náluk lévő előlegekről - legfeljebb azon év végéig, amelyikben a pénztárból kivétették - számadást nyújtsanak be.

A szegedi polgármester rendkívüli sürgős esetekben 500 forint erejéig utalványokat bocsájthatott ki. Ilyen eseteket a tanács legközelebbi ülésén be kellett jelentenie. A polgármester mindkét városban élt azon jogokkal, amelyeket az 1870: XLII. tc. 58. $\$ k$ ) pontja a megyékben az alispánra ruházott. A szegedi polgármester hatáskörébe utalt ügyekről nyilvános iktatókönyvet vezetett a mellé rendelt aljegyző és írnok segítségével.

Szeged és Debrecen város polgárai a polgármester sérelmes határozatai ellen a közgyüléshez és onnan a belügyminiszterhez 15 napon belül föllebbezést nyújthattak be.

A debreceni szervezeti szabályzat a szegedivel ellentétben részletesebben szabályozta a polgármesteri hivatal ügykezelését is. ${ }^{13}$ A törvényhatóságot megillető minden beadványt

MNL CSCSML Szeged város törvényhatósági bizottságának jegyzőkönyvei IV. B. 1402. 1867-1944. 1875:1. Magyar Nemzeti Levéltár Hajdú-Bihar Megyei Levéltára (MNL HBML) Debrecen Városi Tanácsának Iratai (1871) 1872-1929. IV. B. 1405./b.1. 5641/1872., MNL CSCSML Szeged város törvényhatósági bizottságának jegyzőkönyvei IV. B. 1402. 1867-1944. 1871:232-233. 
egy általános iktatókönyvbe, évenként egy folyószámmal vezették be, ami hasonlított a szegedi eljáráshoz. A polgármester osztotta ki naponként a tárgyakat. Az általános iktatókönyvön kívül a polgármesteri hivatalnál egy másik iktatókönyvet is vezettek, amelybe az általános iktatókönyvből a tárgyak csak a számok megjelölésével kerültek. Ebből a könyvből meg lehetett tudni, hogy kinek és mikor adták ki az ügyet, valamint az elintézés idejét és számát is feljegyezték. Mindegyik osztály számára külön könyvet vezettek az elnökségnél, amelybe úgy a kiosztási és átvételi elismervényt, mint az elintézés megjelenési formáját rögzítették. A könyveket a polgármester ellenőrizte.

A koldulás korlátozása, addig, amíg azt végleg meg nem szüntették, engedélyezve volt. A koldusok számontartása, a lelencekről történő gondoskodás, a szegények gyógyíttatása és eltemettetése, az ápolást nem találó szegény sorsú betegek kórházba szállíttatása is a feladatai közé tartozott. A rendőri felügyelet és engedély nélküli építkezéseket betiltotta. A rendőrbiztosokra, a pandúrlegényekre, a hajdúkra, az utcaseprőkre, a tizházgazdákra, az éjjeliőrökre és a gyepmesterre felügyelt. Az egyes dolgozók fegyverzetére való felvigyázás szintén a hivatal hatáskörébe tartozott. A piaci rendet biztosította, különösen a heti vásárok alkalmával és a sertés- és a baromvásárokban, az országos vásárkor a városban, a külső vásárban és a „zsibvásárban”. Az élelmiszerekre való felügyelés tevékenységének jelentős részét képezte. A húsvágókat, nevezetesen a mészárosokat és a henteseket (a borjút, a sertést, a juhot vágókat), a lacikonyhásokat és a pecsenyesütőket felügyelte. A vágóhidak és a vágni való marhák ellenőrzését szükség esetén elvégezte. A fogadókban, a kocsmákban és a gyógytárakban vizsgálatok tartására feljogosították. Felügyelt a fürdőházakra, a színházkertre, a sétányokra és a toronyórák karbantartására. ${ }^{14}$

A polgármester feladatkörét és hivatalának eljárási rendjét alapvetően részletesen szabályozták a városok, érzékeltetve, hogy a polgármester a törvényhatóság első számú tisztviselője, aki így igen jelentős politikai és közigazgatási jogkört gyakorolt.

A polgármestereknél is megállapítható az, ami a főispánoknál, hogy igen aktívan részt vállaltak a helyi ügyek intézésében. A városok első számú tisztviselője meghatározó szerepet töltött be a közigazgatási reformok végrehajtásában és a törvény gyakorlati megvalósításában. ${ }^{15}$

A polgármestert a főjegyző helyettesítette, ezért feladatát röviden szükségesnek tartom ismertetni. A föjegyző mind a két városban a polgármestert akadályoztatása esetén helyettesítette. A szegedi főjegyző általában elnöke volt az árvaszéknek, főfelügyelője a városi

14 MNL CSCSML Szeged város törvényhatósági bizottságának jegyzőkönyvei IV. B. 1402. 1867-1944. 1871:232233., MNL HBML Debrecen Városi Tanácsának Iratai (1871) 1872-1929. IV. B. 1405./b.1. 5641/1872. A polgármesterről: Ruszoly József: Tíz tanulmány a jog-és alkotmánytörténet köréből. Szeged, JATEPress, 1995. 185.

15 A pécsi polgármesterek rövid pályafutásáról: Kajtár István: Önkormányzati élet Pécsett (1848-1949). Baranya, 3. (1990), 61-64. Lásd még: Varga Norbert: A polgári közigazgatás kiépítése felé tett lépések a dualizmus időszakában. In Radics Kálmán (szerk.): A Hajdú-Bihar Megyei Levéltár Évkönyve. XXXI. k. Debrecen, Hajdú Bihar Megyei Levéltár, 2009. A szegedi tisztviselők történetéhez lásd: Ruszoly József: Állandóság és változás a város szervezetben. In Gaál Endre (szerk.): Szeged Története 3. 2. rész. Szeged, Somogyi-könyvtár, 1991. 673674. A vizsgált időszakot közvetlenül megelőző korszak szegedi tisztviselőinek történetéhez: Ruszoly József: A szegedi népképviseleti közgyülés 1848-1871. Szeged, Somogyi-könyvtár, 1984. 
nyilvános és titkos levéltárának, amely utóbbinak egyik kulcsát is őrizte. Felügyelt a városi irodára, az irodai személyzet tevékenységére, a kiadmányozás folyamatára, a közgyűlések jegyzőkönyveit, a közgyülési felterjesztéseket, jelentéseket és leveleket szerkesztette. A törvényhatóság nevében kiállítandó okmányokat elkészítette; a közgyülési tárgyakat a kiadóságtól átvette, és azokról sorozatot készített, végrehajtásukról gondoskodott; az iratokat a közgyülési tagoknak betekintésre átadta és a közgyülésen ismertette; a közgyülési jegyzőkönyvek másolatainak a belügyminisztériumhoz a törvényben meghatározott idő alatti felterjesztéséről intézkedett, és teljesítette a törvény vagy a közgyülés által a főjegyzőre ruházott egyéb kötelezettségeit.

Árvaszéki elnökként az árvaszéki üléseket vezette, az ügyeket feldolgozás és előadás végett kiosztotta, az előadandó ügyek sorrendjét megállapította és intézkedett, hogy az ülésen előadandó tárgyakat a tanácskozási terem ajtajára kifüggesszék. Sürgős ügyek elintézése végett rendkívüli ülések tartásáról is gondoskodott.

Ezzel szemben a debreceni főjegyző jogállását és feladatát a következőképpen határozták meg. A tanácsüléseken szavazati joggal vett részt. A közgyüléseken rendszerint „vitte a tollat,” azaz szerkesztette a közgyülési felterjesztéseket, jelentéseket és leveleket. A törvényhatóság nevében kiállítandó okmányokat elkészítette.

A közgyűlések kihirdetéséről és az ott előadandó tárgyak sorozatának elkészítéséről gondoskodott. A közgyülési jegyzőkönyveket azok hiteles másolataival a belügyminisztériumhoz kellett felterjesztenie a hitelesítéstől számított 30 napon belül.

A városi közlevéltárnak felügyelöje és a rendezésére felügyelö bizottmánynak az elnöke is volt. Felügyelte az iktató, a kiadó és az irodai személyzet tevékenységét és a kiadó által vezetett könyvek pontos vezetését. ${ }^{16}$

Az aljegyzők jogállásának szabályozása jelentősen eltért a két városban. Ennek az oka a köztörvényhatóságok szervezetének különbözőségében keresendő. Szegeden az egyik aljegyző a polgármester mellett és a tanácsüléseken, a másik pedig az árvaszéknél működött, és teljesítette a feladatokat. Az árvaszéki jegyző vezette a jegyzőkönyvet, helyettesítette az ülnököt, az elnök felügyelete alatt végezte és nyilvántartotta az árvakönyveket.

Debrecenben az első aljegyző rendszerint a közigazgatási osztály jegyzőkönyveit vezette. A második aljegyzőt rendszerint a gazdasági osztályba osztották be, és a gazdasági és a jogi, a pénzügyi és az építtetési bizottmányok jegyzőkönyveit vezette, valamint gondoskodott a gazdasági ügyek elintézésére vonatkozó határozatok és javaslatok leíratásáról és kiadmányozásáról. A harmadik aljegyző az árvaszéknél működött. Az aljegyzők szükség esetén előadói minőségben is eljártak, és ilyen esetekben szavazati joggal rendelkeztek. ${ }^{17}$

16 MNL HBML Debrecen Városi Tanácsának Iratai (1871) 1872-1929. IV. B. 1405./b.1. 5641/1872., MNL CSCSML Szeged város törvényhatósági bizottságának jegyzőkönyvei IV. B. 1402. 1867-1944. 1871:233.

${ }_{17}$ MNL HBML Debrecen Városi Tanácsának Iratai (1871) 1872-1929. IV. B. 1405./b.1. 5641/1872., MNL CSCSML Szeged város törvényhatósági bizottságának jegyzőkönyvei IV. B. 1402. 1867-1944. 1871:233. 


\section{A POLGÁRMESTERI FELADAT ELLÁTÁSÁHOZ KAPCSOLÓDÓ HIVATALOK}

A polgármester feladatainak ellátását testületi szervek is segítették, aminek következtében röviden ismertetem e hivatalok eljárását és szervezeti felépítését. Ilyen hivatal volt a városi iroda. Szegeden a városi irodában egy iktató, egy kiadó, hat városi írnok, két bel- és két külterületi kézbesítő dolgozott. Az iroda ügykezelését a polgármester a főjegyzővel együtt határozta meg. Debrecenben az általános iktató-, kiadóhivatalokat együtt szabályozták az irodával. Mindhárom hivatal a főjegyző felügyelete alatt állt. Az iktatókönyvet az iktató vezette.

Az iktató kötelessége volt, hogy ünnep- és vasárnapokon délelőtt 11 órától 12 óráig, a többi napon délelőtt 9 órától 12 óráig, délután 3 órától 5 óráig a beadványokat átvegye. Fel kellett jegyeznie a leglényegesebb tartalmi elemeket és a mellékletben felsorolni a kapcsolódó iratokat. Ezt követően a polgármesterhez kellett átküldenie az anyagot. Lezárta mindennap az iktatókönyvet, amelyben feltüntette a pontos dátumot is.

Az olyan beadványokon, amelyek mellé pénzt is csatoltak, az igazgató annak nagyságát is feljegyezte, és a polgármesterhez, illetve föjegyzőhöz átküldte, hogy azok azonnal utalványozhatók és letéteményezhetők legyenek.

A kiadó vezette a kiadói, a levéltárazási, a kézbesítési, az ügyhátrány, a posta és a pénzküldemény könyveket is. A pénzkönyvbe a küldemény minőségét és mennyiségét bejegyezte, a pénzküldeményekről a tértivevények eredetijét az illetö ügyiratokhoz csatolta, és a pénzkönyvet minden héten a polgármesterhez, illetve a főjegyzőhöz megvizsgálás és aláirás végett benyújtotta. A posta és egyéb aprólékos költségekre kivett előlegekről pontosan okiratokkal ellátott számadást vezetett.

A kiadmányozás végett hozzá érkezett határozatokat átküldte az iktatónak az elintézés bejegyzésére, a kiadmányozás után pedig a közlevéltárnoknak a könyvbeli elismerés elvégzésére. Az ügyhátrányokról jelentést tett a tanácsnak és a közgyülésnek. Írnokok segítették az irodai munka ellátását. ${ }^{18}$

A polgármester beszámolója kapcsán már említettem, hogy a város pénzügyi viszonyait ismerte, amelyhez segítséget a pénztári hivataltól kaphatott. A kifizetéseket egyedül csak a fópénztárnok teljesíthette Szegeden. Minden bevételt és kiadást megfelelő iratok alapján lehetett rögzíteni. Pontosan vezetni kellett a pénztári mellékleteket, a számlákat, a nyugtákat, az ellennyugtákat, a jegyzékeket és a kimutatásokat is.

A segédpénztárakba hetenként befolyt bevételeket, a jogcím megnevezésével összeállított jegyzékeket nyugta és ellennyugta mellett juttatták el a városi föpénztárba. E jegyzék képezte a könyvelés alapját. A befizetések elfogadását és a kifizetések teljesítését délelött 9-től 12 óráig, ünnep- vagy vasárnapok kivételével délután 3-tól 4 óráig lehetett rendezni. Az országos és a heti vásárok alkalmával vagy rendkívüli körülmények között

18 MNL HBML Debrecen Városi Tanácsának Iratai (1871) 1872-1929. IV. B. 1405./b.1. 5641/1872., MNL CSCSML Szeged város törvényhatósági bizottságának jegyzőkönyvei IV. B. 1402. 1867-1944. 1871:233. 
a befizetéseket délután egy óráig lehetett elfogadni. Az összes pénz- és értékpapírkészletet a főpénztárban kellett tartani, a kézitárban csakis a napi szükségletnek megfelelő pénz maradhatott. A hivatalban dolgozott a föpénztárnok, az ellenőr és egy pénztári tiszt. ${ }^{19}$

A főpénztárnok az ellenőrrel és esetleg helyettesítéskor a pénztári tiszttel együtt felelős volt tevékenységük pontos ellátásáért. A föpénztárnok mint a főpénztár kezelője minden, akár közvetlen, akár közvetett bevételt személyesen fogadott el. A kifizetéseket szintén személyesen teljesítette, mindkét esetben a megfelelően felszerelt és kiállított pénztári mellékletek átvétele mellett. A nyugtákat, az ellennyugtákat és az egyéb okmányokat aláírta, és ezeket az ellenőrrel ellenjegyeztette. A pénztárban lévő összegek "gyümölcsöztetésére” felügyelt, és megtett mindent annak érdekében, hogy az ne akadályozza a kiadások rendszeres teljesítését. E tekintetben a fökönyvvivővel egyeztetett.

Mindennap a zárlatnál a pénzkészletet megszámolta, és ezt az ellenőr naplójával összeegyeztette. Köteles volt a kifizetésekről és bevételekről jegyzéket vezetni. Megtekintette a lejárati könyvet a teljesítendő kifizetések és remélhető bevételek miatt. A pénztár egyik kulcsát őrizte.

Debrecenben pénztári hivatalokat hoztak létre, amelyek a következők voltak: házipénztár, alapítványi pénztár, adópénztár és árvapénztár.

A házipénztári hivatal a tanács felügyelete alá tartozott, amely állt a pénztárnokból, az ellenőrből, egy pénztártisztből és egy írnokból. Minden bevételről és kiadásról föés részletes naplót kellett vezetni, amelyek közül az előbbiek a pénztárnál maradtak, a részletes naplókat azonban havonként a hozzá tartozó okmányokkal együtt átvizsgálás végett a számvevő hivatalhoz kellett benyújtani. ${ }^{20} \mathrm{~A}$ biztosítékokról állandó letéti naplót, minden más pénzről pedig kis letéti naplót kellett vezetni. Általában a hivatalhoz utalt tárgyakról segédnaplót készítettek.

Az alapítványi pénztári hivatal állt egy pénztárnokból és egy ellenőrből. Az alapítványokról és az e hivatal körébe utasított egyéb pénzkezelésről külön naplót vezettek. A bevételek és a kiadások számvevői ellenjegyzés mellett történtek. A vagyontalan árvák részére utalványozott segélypénzek fizetése és nyilvántartása is idetartozott. A kiutalványozott kölcsönöket sorrendben kifizették, és az ezekről szóló kötelezvények biztosításáért felelősséget vállalt a tiszti ügyésszel együtt. A pénztári hivatal minden évről számadást készített, és azt időben beterjesztette a tanácshoz, amelynek felügyelete alatt állt.

$\mathrm{Az}$ adópénztári hivatalban a pénztárnok, az ellenőr, egy késedelmikamat-számító és két napdíjas hivatalnok dolgozott. E hivatal az állam érdekében az adókötelesek által fizetett adót átvette, az adókönyvbe beírta, és a naplóba is pontosan nyugtázta. Minden este az adott napon befolyt összeget a napló tételeivel egyeztette, és minden hétvégén a heti bevételeket összesítette, amelyet a királyi adóhivatalnak adtak át. E hivatal az illetékes tanácsnok és a számvevőség felügyelete alatt állt. Mindegyik pénztárnok és ellenőr

19 MNL HBML Debrecen Városi Tanácsának Iratai (1871) 1872-1929. IV. B. 1405./b.1. 5641/1872., MNL CSCSML Szeged város törvényhatósági bizottságának jegyzőkönyvei IV. B. 1402. 1867-1944. 1871:233. 
a legszigorúbb felelösséggel tartozott a munka megfelelő ellátásáért. ${ }^{21} \mathrm{~A}$ testületi szerv feladata leginkább a számadások elkészítéséhez nyújtott információadás kapcsán mutatkozott meg, ami alapján a polgármester ismertetni tudta a város pénzügyi helyzetét a havi és az éves jelentésekben.

A polgármester egyike volt tehát a legfontosabb tisztviselőknek a törvényhatósági jogú városok életében. Az 1870: XLII. tc. szabályozta a rendi hagyományokat sem nélkülöző tisztviselő hatáskörét. Legfontosabb feladata volt a város érdekeinek érvényesítése, amelynek következtében kiemelt érdeklődés kísérte megválasztását és ezt követően hivatali tevékenységét. Egy olyan tisztségről volt szó a magyar közigazgatásban, ami nemcsak a dualista Magyarország közjogi viszonyai között kapott kiemelt szerepet, hanem a mai városigazgatás egyik meghatározó tisztségviselöje is.

21 MNL HBML Debrecen Városi Tanácsának Iratai (1871) 1872-1929. IV. B. 1405./b.1. 5641/1872., MNL CSCSML Szeged város törvényhatósági bizottságának jegyzőkönyvei IV. B. 1402. 1867-1944. 1871:233. 


\section{FELHASZNÁLT IRODALOM}

1. Antal Tamás: Város és népképviselet. Az 1848:XXIII. tc. és intézményei Debrecenben (1848-1872). Szeged, Pólay Elemér Alapítvány, 2011.

2. Balogh Arthur: A magyar államjog alaptanai. Budapest, Franklin, 1901.

3. Csizmadia Andor: A magyar közigazgatás fejlődése a XVIII. századtól a tanácsrendszer létrejöttéig. Budapest, Akadémiai Kiadó, 1976.

4. Csizmadia Andor - Kovács Kálmán - Asztalos László: Magyar állam-és jogtörténet. Budapest, Nemzeti Tankönyvkiadó, 1998.

5. Csorba László: A dualizmus rendszerének kiépülése és a konszolidált időszak (18671890). In Gergely András (szerk.): 19. századi magyar történelem 1790-1918. Budapest, Korona, 1998.

6. Gárdonyi Albert: A polgármesteri tisztség eredete és fejlődése hazánkban. Városi Szemle, 25. (1939), 359-370.

7. Gergely András: Területi autonómiák - lokális önkormányzatok a XIX. századi Magyarországon. In Gergely Jenő - Strausz Péter - Zachar Péter Krisztián (szerk.): Autonómiák Magyarországon 1848-1998. Budapest, ELTE Bölcsészettudományi Kar, 2004.

8. Hencz Aurél: Területrendezési törekvések Magyarországon. Az államigazgatási jogi szabályozás aspektusából. Budapest, Közgazdasági és Jogi Könyvkiadó, 1973.

9. A Hon, 8. (1870), 154.

10. Irinyi Károly: A politikai közgondolkodás és mentalitás változatai Debrecenben 1867-1918. Debrecen, DE Történelmi Intézet, 2002.

11. Kajtár István: Magyar városi önkormányzatok (1848-1918). Budapest, Akadémiai Kiadó, 1992.

12. Kajtár István: Önkormányzati élet Pécsett (1848-1949). Baranya, 3. (1990), 61-64.

13. Mezey Barna: Államosítás és autonómia. Centralizáció és önkormányzatiság a XIX. század második felében. In Gergely Jenő (szerk.): Autonómiák Magyarországon 1848-1998. Budapest, ELTE Bölcsészettudományi Kar, 2004.

14. Nagy Ferencz: A magyar városi jog. Franklin, Budapest, 1912.

15. Meznerics Iván - Torday Lajos: A magyar közigazgatás szervei 1867-1937. Budapest, Magyar Közigazgatástudományi Intézet, 1937.

16. Eöttevényi Nagy Olivér: A magyar közjog tankönyve. Kassa, Vitéz, 1911.

17. Papp László: Az önkormányzatiság vázlatos áttekintése, különös tekintettel a hosszú 19. század alkotmányos megoldásaira. De Jurisprudentia et Iure Publico: Jog-és Politikatudományi Folyóirat, 6. (2012), 1-2. 1-11.

18. Papp László: The Concept of Autonomous Local Governments and their Different Forms of Appearances in the Tradition of our National Public Law. Journal on European History on Law, 3. (2012), 1. 62-65.

19. Pétervári Máté: Ereky István élete és munkássága, tekintettel a 19. század második felében történt közigazgatási reformokra. Jogtörténeti Szemle, (2014), 3. 29-38. 
20. Pétervári Máté: Az igazságszolgáltatás és a közigazgatás elválasztása járási szinten. Acta Universitatis Szegediensis: Forum: Acta Juridica et Politica, 8. (2018), 1. 241-253.

21. Pétervári Máté: A járások polgári kialakítását befolyásoló tényezők az 1870:XLII. tc. végrehajtása során. In P. Szabó Béla - Zaccaria Márton Leó - Árva Zsuzsanna (szerk.:) Profectus in Litteris IX. Elöadások a 14. debreceni állam-és jogtudományi doktorandusz-konferencián. Debrecen, Lícium-Art, 2017.

22. Pétervári Máté: A szolgabírói hivatal az 1870. évi XLII. törvénycikk alapján. Pro Publico Bono - Magyar Közigazgatás, (2018), 3. 56-78.

23. Pétervári Máté: The History of Hungarian Civil Service from the Austrian-Hungarian Compromise of 1867 to the First World War. Journal on European History on Law, 8. (2017), 1. 116-120.

24. Ruszoly József: Állandóság és változás a városi szervezetben. In Gaál Endre (szerk.): Szeged Története 3. 2. rész. Szeged, Somogyi-könyvtár, 1991.

25. Ruszoly József: A szegedi népképviseleti közgyülés 1848-1871. Szeged, Somogyikönyvtár, 1984.

26. Ruszoly József: Tíz tanulmány a jog-és alkotmánytörténet köréből. Szeged, JATEPress, 1995. 185.

27. Sarlós Béla: Közigazgatás és hatalompolitika a dualizmus rendszerében. Budapest, Akadémiai Kiadó, 1876.

28. Varga Norbert: A polgári közigazgatás kiépítése felé tett lépések a dualizmus időszakában. In Radics Kálmán (szerk.): A Hajdú-Bihar Megyei Levéltár Évkönyve. XXXI. k. Debrecen, Hajdú Bihar Megyei Levéltár, 2009.

29. A városi számvevő- s ellenőrzőszék. Alföldi Hírlap, (1871), 152.

Jogi forrás

1. 1870. évi XLII. törvénycikk a köztörvényhatóságok rendezéséről

Levéltári forrás

1. Magyar Nemzeti Levéltér Csongrád-Csanád Megyei Levéltára Szeged város törvényhatósági bizottságának jegyzőkönyvei IV. B. 1402. 
Dr. Varga Norbert a Debreceni Egyetem Jog-és Államtudományi Intézetben 2001-ben szerzett jogász diplomát. 2002-ben rövidebb ideig a Max Planck Institut adott otthont kutatásainak Frankfurt am Mainban. A holland Amsterdam Law School és az egyesült államokbeli Indiana University, Maurer School of Law által támogatott doktori részképzésekben vett részt. Kutatásokat folytatott a Harvard University jogi karán. Kutatási területe a 19. századi magyar állampolgársági jog, amely témában 2009-ben doktori (PhD-) fokozatot szerzett. 2003-2006 között a Debreceni Egyetem Bölcsészettudományi Karának Történelmi Intézetében szerzett történész végzettséget, majd 2008-ban történelemből is megvédte a PhD-disszertációját. Jelenleg egyetemi docensként dolgozik a Szegedi Tudományegyetem Állam- és Jogtudományi Kar Magyar Jogtörténeti Tanszékén, 2017-től kezdve a kar tudományos ügyekért felelős dékánhelyettese, a Gateway kínai magyar csereprogram igazgatója. Külföldi tanulmányutakon vett részt többek között az Oxfordi Egyetemen, a Cambridge Egyetemen, a Heidelbergi Egyetemen, a Krakkói és a Zágrábi Egyetemen. Több nemzetközi és hazai jogtörténeti társaság tagja, pályázatok és kutatócsoportok aktív résztvevője, témavezetője tudományos diákköri és doktori képzésben részt vevő hallgatóknak. Számos előadást tartott és tanulmányt jelentetett meg angol és magyar nyelven. 